\title{
PERAN PENDIDIKAN DALAM PROSES PEMBELAJARAN INKLUSIF (STUDI KASUS DI SD MUHAMMADIYAH DADAPAN KABUPATEN SLEMAN)
}

\author{
Arum Umamil Banati \\ Nurul Hidayati Rofiah \\ PGSD FKIP Universitas Ahmad Dahlan \\ arumumamil@gmail.com
}

\begin{abstract}
Inclusive learning is to provide a service system for children with special needs to be served in the nearest school or regular school with their peers. In the implementation of inclusive learning in schools requires serious handling from related parties, especially parents, the school, government and the community. Therefore, researchers want to know how the role of educators in the inclusive learning process in SD Muhammadiyah Dadapan Sleman District. This research is a qualitative research with descriptive approach of case study. The subject of this research is principal, classroom teacher, subject teacher, special tutor and student. Target object in this research is the role of educator (classroom teacher, special tutor, and children with special needs) in inclusive learning at SD Muhammadiyah Dadapan, Sleman District.

Based on the research results obtained conclusions as follows: (1) Educators referred to in this study are classroom teachers, special tutors and subject teachers. The role of special mentor teachers is only as a consultant if the class teacher has difficulty in guiding students with special needs during the learning process in the classroom. The role of classroom teachers and subject teachers is crucial in the inclusive learning process, in schools because students with special needs are more often guided by classroom teachers and subject teachers. (2) Competent educators will be better able to create an effective, enjoyable learning environment, and will be better able to manage the class, so that learning can run optimally. To create a conducive learning atmosphere the educator must have 4 competencies, namely pedagogic competence, personality competence, social competence, and professionalism.
\end{abstract}

Keywords: Inclusive Learning, the Role of Educators, Educators' Competencies

\begin{abstract}
ABSTRAK
Pembelajaran inklusif adalah memberikan sistem layanan bagi anak berkebutuhan khusus dilayani di sekolah terdekat maupun sekolah regular bersama dengan teman-teman sebayanya.Dalam penyelenggaraan proses pembelajaran inklusif di sekolah membutuhkan penanganan secara serius dari pihak terkait, terutama orangtua, pihak sekolah, pemerintah, dan masyarakat. Oleh sebab itu peneliti ingin mengetahui bagaimana peran pendidik dalam proses pembelajaran inklusif di SD Muhammadiyah Dadapan Kabupaten Sleman. Penelitian ini merupakan penelitian kualitatif dengan pendekatan deskriptif studi kasus.Subjek penelitian ini adalah kepala sekolah, guru kelas, guru mata pelajaran, guru pembimbing khusus dan siswa.Objek sasaran dalam penelitian ini adalah peran pendidik (guru kelas, guru pembimbing khusus, guru mata pelajaran dan anak berkebutuhan khusus) dalam pembelajaran inklusif di SD Muhammadiyah Dadapan, Kabupaten Sleman.
\end{abstract}


Berdasarkan hasil penelitian diperoleh kesimpulan sebagai berikut: (1) Pendidik yang dimaksud dalam penelitian ini ialah guru kelas, guru pembimbing khusus dan guru mata pelajaran. Peran guru pembimbing khusus yaitu hanya sebagai konsultan apabila guru kelas mengalami kesulitan dalam membimbing siswa berkebutuhan khusus saat proses pembelajaran di kelas. Peran guru kelas dan guru mata pelajaran sangat menentukan dalam proses pembelajaran inklusif, di sekolah karena siswa berkebutuhan khusus lebih sering dibimbing oleh guru kelas dan guru mata pelajaran. (2) Pendidik yang berkompeten akan lebih mampu menciptakan lingkungan belajar yang efektif, menyenangkan, dan akan lebih mampu mengelola kelas, sehingga pembelajaran dapat berjalan secara optimal. Untuk menciptakan suasana belajar yang kondusif maka pendidik harus memiliki 4 kompetensi, yaitu kompetensi pedagogik, kompetensi kepribadian, kompetensi sosial, dan profesionalisme.

Kata kunci: Pembelajaran Inklusif, Peran Pendidik, Kompetensi Pendidik

\section{PENDAHULUAN}

Peraturan Walikota Yogyakarta Nomor 47 tahun 2008 tentang penyelenggara pendidikan Inklusif pada Bab II Pasal 3 yaitu tujuan penyelenggaraan pendidikan inklusi dapat memberikan hak yang sama dalam pelayanan pendidikan kepada seluruh peserta didik dengan mengembangkan bakat dan potensi yang dimiliki sehingga mencapai kemandirian di keluarga, masyarakat, dan bangsa.Konsep pendidikan inklusi ialah memberikan sistem layanan bagi anak berkebutuhan khusus dilayani di sekolah terdekat maupun sekolah regular bersama dengan teman-teman sebayanya. (Ilahi, 2013). Dalam penyelenggaraan pembelajaran inklusif di sekolah membutuhkan penanganan secara serius dari pihak terkait, terutama orangtua, pihak sekolah, pemerintah, dan masyarakat.Tugas seorang guru menurut Undang-Undang Tentang Guru dan Dosen No.14 Tahun 2005 pasal 1 adalah pendidik profesional dengan tugas utama yaitu mendidik, mengajar, membimbing, mengarahkan, melatih, menilai, dan mengevaluasi peserta didik pada pendidikan anak usia dini, pendidikan dasar, pendidikan menengah dan pendidikan formal.Guru pembimbing khusus sesuai dengan buku pedoman penyelanggarapendidikan inklusif tahun 2007 adalah guru yang mempunyai latarbelakang pendidikan khusus/Pendidikan luar biasa atau yang pernah mendapat pelatihan tentang pendidikan khusus/luar biasa, yang ditugaskan di sekolah inklusif.

Berdasarkan hasil wawancara awal dengan salah satu guru SD Muhammadiyah Dadapan pada tanggal 19 Desember 2016 pada Tahun Pelajaran 2015/2016sekolah memiliki 14 siswa berkebutuhan khusus. Tahun Pelajaran 2016/2017 sekolah memiliki 20 siswa berkebutuhan khusus Jumlah guru dan karyawan dengan pendidikan terakhir S1 lebih banyak dari SMA. Jumlah guru dan karyawan dengan pendidikan terakhir S2 yaitu 1, S1 berjumlah 11, dan SMA berjumlah 3. Guru di SD Muhammadiyah Dadapan merupakan guru kelas, sehingga sebagai guru kelas dituntut harus mampu menguasai semua mata pelajaran yang akan diberikan kepada siswa. Sedangkan, guru pembimbing khusus di SD Muhammadiyah Dadapan berjumlah 1. Tugas guru pembimbing khusus di sekolah ini ialah sebagai konsultan antara guru pendamping kelas apabila menghadapi kesulitan saat membimbing siswa berkebutuhan khusus selama proses belajar mengajar di kelas.

Pembelajaran inklusif adalah upaya memposisikan anak berkebutuhan khusus untuk mendapatkan perlakuan manusiawi, pendidikan yang bermutu, dan sesuai potensi setiap individu tanpa adanya diskriminatif yang dapat merugikan eksistensi kehidupannya. (Hermanto, 2010: 67) Pembelajaran inklusi mewujudkan penyelenggaraan pendidikan kepada anak berkebutuhan khusus dengan anak yang normal tanpa membedakan atau diskriminatif satu sama lain dengan peserta didik yang memiliki emosional, mental, 
kelainan fisik dan sosial serta memiliki potensi kecerdasan dan bakat istimewa untuk memperoleh layanan pendidikan yang berkualitas untuk mencapai tujuan pendidikan nasional dengan baik. Dalam pembelajaran inklusif di sekolah dasar yang harus diperhatikan ada beberapa komponen-komponen pendukung antara lain yaitu memahami pengertian pembelajaran inklusif, landasan pendidikan inklusi, komponen pendidikan inklusif. Peran pendidik diharapkan mampu mengatasi beberapa hambatan atau masalah anak berkebutuhan khusus dalam proses pembelajaran di kelas sehingga tercipta suasana kelas yang kondusif.

Peneliti juga melakukan observasi awal pada tanggal 29 April 2017 yang menunjukkan bahwa proses pembelajaran inklusif di kelas belum sesuai dengan rencana penyelenggaraan pendidikan inklusif, fasilitas dan sarana belajar khusus bagi anak berkebutuhan khusus yang tersedia di SD Muhammadiyah Dadapan masih perlu dilengkapi, belum tersedianya ruangan khusus, alat penunjang dan buku penunjang layanan anak berkebutuhan khusus belum lengkap, hal ini menjadi salah satu hambatan bagi pembelajaran inklusif di sekolah. Guru pembimbing khusus juga tidak melayani bimbingan konseling saat pembelajaran di kelas.

Berdasarkan uraian diatas dapat disimpulkan bahwa dalam proses pembelajaran inklusif di sekolah membutuhkan penanganan secara serius dari beberapa pihak, maka peneliti mengangkat judul "Peran Pendidik dalam Proses Pembelajaran Inklusif (Studi Kasus di SD Muhammadiyah Dadapan Kabupaten Sleman)" Berdasarkan latar belakang tersebut di atas maka dapat diperoleh identifikasi masalah sebagai berikut: 1) Minimnya guru pembimbing khusus yang tersedia di sekolah. 2) Proses pembelajaran inklusif di kelas belum sesuai dengan rencana penyelenggaraan pendidikan inklusif. 3) Kurangnya peran maksimal guru pembimbing khusus di SD Muhammadiyah Dadapan. 4) Fasilitas dan sarana belajar khusus bagi anak berkebutuhan khusus yang tersedia belum lengkap. 5) Pentingnya peran guru merupakan salah satu faktor utama dalam pembelajaran inklusif. Berdasarkan batasan masalah yang ada, maka dapat dirumuskan permasalahan dalam penelitian ini, yakni bagaimana peran pendidik (guru kelas, guru mata pelajaran dan guru pembimbing khusus) dalam proses pembelajaran inklusif di SD Muhammadiyah Dadapan Kabupaten Sleman?

Tujuan yang ingin dicapai dari penelitian adalah untuk mengetahui peran pendidik yaitu guru kelas, guru mata pelajaran dan guru pembimbing khusus dalam proses pembelajaran di SD Muhammadiyah Dadapan Kabupaten Sleman dalam pendampingan anak berkebutuhan khusus di sekolah. Dan penelitian ini nantinya juga akan memberikan manfaat praktis maupun teoritisnya.

Menurut Gary Flewelling dan William Higginson (Suyono dan Hariyanto, 2012: 188) menggambarkan peran guru antara lain: (1) memberikan stimulasi kepada siswa untuk meningkatkan perkembangan intelektual, emosional, spiritual, dan sosial, (2) berinteraksi dengan siswa untuk mendorong keberanian, (3) bermanfaat setelah memperlajari suatu poko bahasan, (4) berperan sebagai yang membantu dan pemberi informasi.Selain itu, menurut (Hamalik, 2014: 9) pendidik merupakan suatu komponen yang penting dalam penyelenggaraan pendidikan, yang bertugas mengajar, melatih, meneliti, mengembangkan, mengelola dan memberikan pelayanan teknis dalam bidang pendidikan. Jadi, pendidik dalam pembelajaran inklusif adalah seorang guru yang memenuhi kriteria professional (fisik, mental atau kepribadian, pengetahuan dan keterampilan) yang bertugas mendidik siswa reguler dan siswa berkebutuhan khusus dalam pembelajaran di kelas secara bersama untuk meningkatkan perkembangan intelektual, emosional, spiritual, dan sosial.

Menurut Peraturan Pemerintah Republik Indonesia Nomor 74 Tahun 2008 tentang Guru Bab II, Kompetensi dan Serifikasi Pasal 3 menyebutkan bahwa: "Kompetensi 
merupakan seperangkat pengetahuan, keterampilan, dan perilaku yang harus dimiliki, dihayati, dikuasai, dan diaktualisasikan oleh guru dalam melaksanakan tugas keprofesionalan." Selain itu, menurut (Ilahi, 2013: 179) untuk menciptakan suasana belajar yang kondusif maka pendidik atau guru harus memiliki 4 kompetensi, yaitu kompetensi pedagogik, kompetensi kepribadian, kompetensi sosial, dan profesionalisme.

\section{METODE PENELITIAN}

Jenis penelitian ini adalah penelitia kualitatif. Teknik penelitian yang digunakan dalam pengumpulan data berupa wawancara, observasi dan dokumentasi. Sekolah Dasar Muhammadiyah Dadapan Kabupaten Sleman terletak di Dusun Dadapan, Wonokerto, Turi, Sleman, Yogyakarta. Peneliti akan meneliti tentang peran pendidik (guru kelas, guru pembimbing khusus, dan guru mata pelajaran) dalam pembelajaran inklusif di sekolah tersebut. Waktu penelitian dilakukan antara Bulan Mei sampai Bulan Juni 2017 setelah ada persetujuan dari berbagai pihak. Subjek sasaran dalam penelitian ini adalah kepala sekolah, guru kelas, guru pembimbing khusus, guru mata pelajaran dan anak berkebutuhan khusus.

Objek sasaran dalam penelitian ini adalah peran pendidik (guru kelas, guru pembimbing khusus, guru mata pelajaran dan anak berkebutuhan khusus) dalam pembelajaran inklusif di SD Muhammadiyah Dadapan, Kabupaten Sleman. Pada penelitian ini menggunakan metode triangulasi yang bersifat menggabungkan dari berbagai teknik pengumpulan data dan sumber data .dengan cara wawancara, observasi dan dokumentasi (Moleong, 2012). Penelitian ini menggunakan teknik analisis data model Miles dan Huberman (Sugiono, 2012) menyatakan bahwa dalam analisis data kualitatif meliputi: reduksi data (data reduction), penyajian data (display data),kesimpulan dan verifikasi (verification/conclusion drawing).

\section{HASIL DAN PEMBAHASAN}

\section{Deskripsi Lokasi Penelitian}

SD Muhammadiyah Dadapan Kabupaten Sleman terletak di Dusun Dadapan, Desa Wonokerto, Kecamatan Turi, Kabupaten Sleman. SD Muhammadiyah Dadapan Kabupaten Sleman adalah sekolah yang ditunjuk oleh dinas pendidikan provinsi Yogyakarta sejak Tahun 2010 sebagai sekolah penyelenggara pendidikan inklusif. Sekolah ini menerima anak berkebutuhan khusus yang dapat belajar bersama dengan siswa regular pada umumnya. Berdasarkan penelitian, Hasil assemen anak berkebutuhan khusus di SD Muhammadiyah Dadapan Tahun 2016/2017 menunjukan siswa tunadaksa ringan 4\%, siswa tunagrahita $4 \%$, siswa Low vision $8 \%$, dan siswa lambat belajar $84 \%$. Menunjukkan bahwa sebagian besar siswa mengalami lambat belajar, dengan jumlah siswa 20 orang.

\section{Hasil Penelitian}

Berdasarkan hasil wawancara dan observasi dalam penelitian serta data dukung dalam pembelajaran inklusif di SD Muhammadiyah Dadapan Kabupaten Sleman, sebagian besar atau dominan dari peran guru kelas, sedangkan guru pembimbing khusus sebagai konsultan atau pembimbing guru lain apabila mendapatkan kesulitan saat menghadapi siswa berkebutuhan khusus dalam proses pembelajaran di kelas. Tetapi dalam pelaksanaan tersebut masih ada beberapa kendala atau masalah yang dihadapi pendidik yang perlu diperhatikan dalam penyelenggaraan pendidikan inklusif di sekolah.antara lain:

a) Kondisi guru

Keterbatasan guru dalam mendampingi siswa berkebutuhan khusus saat di kelas, terkadang juga membuat emosional guru menjadi tidak stabil. Mengakibatkan siswa menjadi takut terhadap guru apabila sang guru memberi perintah kepada siswa tersebut. Guru juga terkadang harus memberi perhatian khusus kepada siswa 
berkebutuhankhusus karena mereka memperlukan bantuan yang tidak siswa reguler lainnya butuhkan, seperti guru harus mengulang beberapa kali untuk memahamkan siswa itu tentang materi tertentu.

b) Kebijakan sekolah

Hambatan yang dihadapi di SD Muhammadiyah Dadapan ini dalam pembelajaran inklusif yaitu masih terdapat kebijakan sekolah yang kurang tepat, antara lain kurangnya tanggungjawab guru pembimbing khusus pada kemajuan belajar siswa berkebuthan khusus serta keharusan orangtua siswa berkebutuhan khusus menyediakan guru khusus.

c) Proses pembelajaran

Adanya Program Pembelajaran Individu (PPI) sejauh ini disusun oleh guru pembimbing khusus bukan disusun oleh guru kelas. Pada saat proses pembelajaran, guru kelas tidak dapat melaksanakan kegiatan sesuai Program Pembelajaran Individu (PPI) dikarenakan keterbatasan waktu dan kondisi masing-masing siswa berkebutuhan khusus. Maka, guru kelas harus menyediakan soal latihan yang berbeda antara siswa berkebutuhan khusus dengan siswa reguler

d) Peran pemerintah

Belum adanya dukungan dan koordinasi tenaga professional atau institusi terkait untuk mengadakan pelatihan ataupun sosialisasi dalam membimbing siswa berkebutuhan khusus bagi guru kelas dan guru mata pelajaran saat proses pembelajaran inklusif di SD Muhammadiyah Dadapan. Dinas terkait dinilai kurang proaktif terhadap permasalahan nyata yang ada di sekolah.

\section{KESIMPULAN}

Pendidik yang dimaksud dalam penelitian ini ialah guru kelas, guru pembimbing khusus dan guru mata pelajaran. Peran guru pembimbing khusus yaitu hanya sebagai konsultan apabila guru kelas mengalami kesulitan dalam membimbing siswa berkebutuhan khusus saat proses pembelajaran di kelas, guru pembimbing khusus jarang membimbing siswa berkebutuhan khusus secara langsung saat proses pembelajaran di kelas. Peran guru kelas dan guru mata pelajaran sangat menentukan dalam proses pembelajaran inklusif, di sekolah karena siswa berkebutuhan khusus lebih sering dibimbing oleh guru kelas dan guru mata pelajaran. Tenaga pendidik dalam pelaksanaan pembelajaran di kelas harus dapat menjalin kerja sama dengan semua pihak.

Kompetensi pendidik untuk menciptakan suasana pembelajarn inklusif yang kondusif: Kompetensi pedagogic, guru sudah mampu dalam mengelola pembelajaran peserta didik antara lain perkembangan anak berkebutuhan khusus, pelaksanaan pembelajaran di kelas, bimbingan khusus di luar pembelajaran dan evaluasi hasil belajar secara rutin. Kompetensi kepribadian, sosok guru selama pembelajaran di kelas menjadi contoh teladan peserta didik. Guru pendamping kelas dan guru mata pelajaraan mampu menjadi sosok yang dewasa, sabar, dan rajin dalam membimbing peserta didik khususnya menghadapi anak berkebutuhan khusus. Kompetensi social, kemampuan pendidik dalam berkomunikasi dengan ramah, sopan dan melibatkan masyarakat di sekitar sekolah. Guru membaur dengan sesama guru dan karyawan tanpa adanya diskriminasi, tampak harmonis. Kompetensi professional Kemampuan guru dalam dalam menangani siswa berkebutuhan khusus dalam pembelajaran di kelas yaitu membimbing dan membantu mengatasi kesulitan siswa berkebutuhan khusus di kelas.

Hasil yang telah diperoleh dari imlpemntasi pembelajaran inklusif yang utama adalah sekolah ini siswa berkebutuhan khusus menjuarai peringkat I Lomba Olimpiade Nasional Matematika Tahun 2012 yang diselenggarakan di Bali.Kemudian selain kejuaraan tersebutsiswa yang telah tamat dari SD Muhammadiyah Dadapan Kabupaten Sleman ini 
khususnya, siswa berkebutuhan khusus adanya peningkatan perilaku dan karakter baik yang berlandaskan religius.

\section{DAFTAR PUSTAKA}

Ilahi, M. T. 2013. PENDIDIKAN IKLUSIF: Konsep dan Aplikasi. Yogyakrta: Ar-Ruzz Media.

Moleong, L. J. 2012. Metedologi Penelitian Kualitatif. Bandung: Remaja Rosdakarya.

Peraturan Walikota Yogyakarta Nomor 47 tahun 2008. Penyelenggara Pendidikan Inklusif. Diakses dari: hukum.jogjakota.go.id/data/Pe rwal\%2047\%20th\%202008.pdf.Diakses pada tanggal 15 Januari 2017 jam 14.00 WIB

Hamalik, O. 2010. Pendidikan Guru Berdasarkan Pendekatan Kompetensi. Jakarta: Bumi Aksara.

Hermanto. 2010. "Penyelenggaraan Pendidikan Inklusif Membutuhkan Keseriusan Manajemen Sekolah". Diakses dari: staff.uny.ac.id/.../penelitian/Hermanto..../PROPOSAL\%20HIBAH\%... Pada tanggal 20 Januari 2017 jam 14.00 WIB

Suharsimi, Arikunto. 2006. Prosedur Penelitian Suatu Pendekatan Praktek. Jakarta: Rineka Cipta.

Sugiono. 2010. Metode Penelitian Pendidikan. Bandung: Alfabeta.

Suyono, Hariyanto. (2012). Belajar Dan Pembelajaran. Bandung:Remaja Rosdakarya. 